\section{NTS 2020/37}

\author{
HR 11 februari 2020, 17/02107,
}

ECLI:NL:HR:2020:232

Omvang terugmijzingsopdracht na cassatie. Omvat door $H R$ uitgesproken vernietiging en terugmijzing t.z.v. de strafoplegging tevens de beslissing van het hof tot strafbepaling ex art. $423.4 \mathrm{~Sv}$ ?

\section{Aantekening redactie}

Indien bij samenloop van meerdere feiten één hoofdstraf is uitgesproken en het hoger beroep slechts ingesteld is ten aanzien van een of meer dier feiten, wordt, in geval van vernietiging ten aanzien van de straf, bij het arrest de straf voor het andere feit of de andere feiten bepaald (art. 423 lid $4 \mathrm{~Sv}$ ). De uitleg van deze bepaling zorgde voor enige hoofdbrekens in de onderhavige zaak. Wat was het geval? Welnu, de rechtbank heeft bij vonnis van 2 augustus 2013 de verdachte ter zake van de onder 1, 2,

3,4 en 5 bewezen verklaarde misdrijven veroordeeld tot een gevangenisstraf van achttien maanden, waarvan zes maanden voorwaardelijk met een proeftijd van twee jaar. Daarnaast heeft de rechtbank ten aanzien van feit 2 de vordering van de benadeelde partij toegewezen en een schadevergoedingsmaatregel opgelegd. Nadat de verdachte tegen dat vonnis onbeperkt hoger beroep heeft ingesteld, is het hoger beroep bij akte ingetrokken ten aanzien van de feiten 3, 4 en 5. Het hof heeft bij arrest van 19 november 2014 het vonnis van de rechtbank, voor zover aan zijn oordeel onderworpen, vernietigd. Het hof heeft de verdachte ter zake van de feiten 1 en 2 veroordeeld tot een gevangenisstraf van tien maanden waarvan zes maanden voorwaardelijk met een proeftijd van twee jaar. Daarnaast heeft het hof ter zake van het onder 2 bewezen verklaarde de vordering van de benadeelde partij gedeeltelijk toegewezen en een schadevergoedingsmaatregel opgelegd. Het hof heeft ten slotte de straf voor de door de rechtbank bewezen verklaarde feiten 3,4 en 5 bepaald op een gevangenisstraf van drie maanden met aftrek van voorarrest. So far so good. De verdachte heeft tegen dit arrest van het hof onbeperkt beroep in cassatie ingesteld. De Hoge Raad heeft bij arrest van 6 september 2016 het arrest van het hof van 19 november 2014 vernietigd 'maar uitsluitend wat betreft de beslissingen ter zake van het onder 1 tenlastegelegde en de strafoplegging', en de zaak teruggewezen naar het hof 'opdat de zaak in zoverre op het bestaande hoger beroep opnieuw wordt berecht en afgedaan'. De vraag was nu wat de implicaties zijn van deze terugwij- zingsopdracht. Het hof heeft, na die terugwijzing door de Hoge Raad, bij arrest van 7 april 2017 het vonnis van de rechtbank, voor zover aan zijn oordeel onderworpen, vernietigd en feit 1 bewezen verklaard. Het dictum van het arrest van het hof hield verder in:

'ten aanzien van feit 1 en 2: veroordeelt de verdachte tot een taakstraf voor de duur van 240 (tweehonderdveertig) uren, indien niet naar behoren verricht te vervangen door 120 (honderdtwintig) dagen hechtenis; veroordeelt de verdachte tot een gevangenisstraf voor de duur van 4 (vier) maanden; bepaalt dat de gevangenisstraf niet ten uitvoer zal worden gelegd, tenzij de rechter later anders mocht gelasten omdat de verdachte zich voor het einde van een proeftijd van 2 (twee) jaren aan een strafbaar feit heeft schuldig gemaakt; ingevolge het arrest van dit hof van 19 november 2014: stelt vast dat de verdachte ter zake van de feiten 3 primair, 4 en 5 is veroordeeld tot een gevangenisstraf voor de duur van 3 (drie) maanden met aftrek van de tijd die door de verdachte vóór de tenuitvoerlegging van deze uitspraak in enige in artikel 27, eerste lid of artikel 27 a van het Wetboek van Strafrecht bedoelde vorm van voorarrest is doorgebracht, voor zover die tijd niet reeds op een andere straf in mindering is gebracht; stelt vast dat de vordering tot schadevergoeding van de benadeelde partij [benadeelde] ter zake van het onder 2 bewezen verklaarde tot het bedrag van $€ 15.155,53$ (vijftienduizend honderdvijfenvijftig euro en drieënvijftig cent) ter zake van materiële schade is toegewezen (...); stelt vast dat aan de verdachte de verplichting is opgelegd om aan de Staat, ten behoeve van het slachtoffer, genaamd [benadeelde], een bedrag te betalen van $€ 15.155,53$ (vijftienduizend honderdvijfenvijftig euro en drieënvijftig cent) als vergoeding voor materiële schade (...); stelt vast dat de benadeelde partij voor het overige niet-ontvankelijk is verklaard in haar vordering.'

Door de raadsman was echter aangevoerd dat de terugwijzing door de Hoge Raad voor zowel feit 1 als de straftoemeting, betekende dat voor wat betreft de strafmaat de volledige straf (dus ter zake van de feiten 1, 2, 3, 4 en 5) bij de strafbepaling weer aan de orde was. Daar dacht het hof anders over, namelijk dat de term 'strafoplegging' niet ziet op de straf die het hof bij arrest van 19 november 2014 reeds heeft bepaald ter zake van de feiten 3, 4 en 5. De straf voor deze feiten (een gevangenisstraf voor de duur van drie maanden, met aftrek van voorarrest) is bepaald en was na verwijzing niet meer aan de orde. Het middel klaagde dat het hof, na de terugwijzing van de zaak door de Hoge Raad, niet alleen een straf had moeten opleggen voor de feiten 1 en 2, maar tevens op grond van artikel 423 lid $4 \mathrm{~Sv}$ een straf had moeten bepalen voor de feiten 3,4 en 5 . Dat deze zienswijze onjuist is zit ' $m$ in het feit dat van 'strafoplegging' geen sprake is indien de rechter in hoger beroep op grond van artikel 423 lid $4 \mathrm{~Sv}$ de sanctie heeft bepaald met betrekking tot de door de rechter in eerste aanleg bemezen 
verklaarde feiten ter zake waarvan de veroordeling al onherroepelijk is geworden. ${ }^{24}$ Met een dergelijke beslissing legt het hof immers niet zelf een sanctie op die het passend en geboden acht ter zake van het feit dat of de feiten die niet aan zijn oordeel onderworpen is/zijn, maar bepaalt het slechts welk gedeelte van de hoofdstraf en/of bijkomende straf(fen) en/of maatregel(en) geacht moet(en) worden door de eerste rechter te zijn opgelegd ter zake van het feit dat of de feiten die niet aan het oordeel van het hof is/zijn onderworpen. ${ }^{25}$ In een vernietiging 'wat betreft de strafoplegging' zijn dan ook niet begrepen beslissingen als bedoeld in artikel 423 lid $4 \mathrm{~Sv}$. Indien de Hoge Raad een bestreden uitspraak 'wat betreft de strafoplegging' vernietigt, bliift de beslissing in die uitspraak met betrekking tot het bepalen van de straf dus in stand. Dat is anders indien de bestreden uitspraak van het hof algeheel wordt vernietigd. In dat geval omvat de vernietiging van die uitspraak ook de in artikel 423 lid 4 Sv bedoelde beslissing. De Hoge Raad acht het oordeel van het hof dat het in zijn arrest van 7 april 2017 niet meer had te oordelen over de sanctieoplegging voor de feiten 3, 4 en 5, omdat bij arrest van het hof van 19 november 2014 de straf voor die feiten al was bepaald en die strafbepaling na terugwijzing door de Hoge Raad niet meer aan de orde was, dan ook juist. Hij voegt daar echter nog wel het volgende aan toe:

'In de vernietiging "wat betreft de strafoplegging" zijn in beginsel niet begrepen de beslissingen als bedoeld in art. $361 \mathrm{~Sv}$ omtrent een vordering van de benadeelde partij, nu die beslissingen worden bepaald door de civielrechtelijke rechtsverhouding tussen de verdachte en de benadeelde partij.

Van de beslissing omtrent een vordering van de benadeelde partij moet worden onderscheiden de beslissing ter zake van het opleggen van een schadevergoedingsmaatregel als bedoeld in art. 36f Sr. De oplegging van de schadevergoedingsmaatregel is wel begrepen in de vernietiging "wat betreft de strafoplegging", tenzij anders wordt vermeld in de uitspraak van de Hoge Raad.

Aanleiding voor zo'n andersluidende beslissing van de Hoge Raad kan bijvoorbeeld bestaan in het geval dat in de bestreden uitspraak meerdere feiten zijn bewezenverklaard en ten aanzien van verschillende van die feiten een vordering van een benadeelde partij is toegewezen, terwijl de vernietiging door de Hoge Raad wordt beperkt tot één van die feiten. De vernietiging van de beslissingen met betrekking tot dat feit omvat dan de toewijzing van de vordering van de benadeelde partij die betrekking heeft op dat feit, maar niet de toewijzing van de vordering(en) met betrekking tot de overige bewezenverklaarde feiten. Dat kan anleiding vormen om de schadevergoedingsmaatregel(en) die is (of zijn) opgelegd met betrekking tot de schade die is veroorzaakt door de feiten waarvan de bewezenverklaring in stand blijft,

24. Vgl. ook met betrekking tot art. 359 lid 5 en 6 Sv HR 9 mei 2000 ECLI:NL:HR:2000:AA5734.

25. Vgl. HR 2 februari 2010, ECLI:NL:HR:2010:BK3202. buiten de vernietiging van de strafoplegging te houden. Een voorbeeld daarvan betreft HR 27 januari 2015, ECLI:NL:HR:2015:132.

Voorts kan worden gewezen op het geval waarin de grond voor cassatie uitsluitend is gelegen in de (gehele of gedeeltelijke) toewijzing van de vordering van de benadeelde partij, terwijl in verband met die toewijzing tevens een schadevergoedingsmaatregel voor hetzelfde bedrag is opgelegd. In dat geval wordt in beginsel de bestreden uitspraak uitsluitend vernietigd met betrekking tot de beslissing op die vordering en de oplegging van de schadevergoedingsmaatregel en niet met betrekking tot de strafoplegging als geheel.'

\section{NTS 2020/38}

HR 4 februari 2020, 19/03651, ECLI:NL:HR:

2020:185

OM-cassatie. Beklag, beslag ex art. 94 Sv op gegevensdragers onder kla(a)g(st)er(s) i.v.m. onderzoek naar OMG Caloh Wagoh, art. $552 a$ Sv

\section{Aantekening redactie}

In verband met het onderzoek naar motorbende Caloh Wagoh is (o.m.) onder klager op grond van artikel $94 \mathrm{~Sv}$ een groot aantal gegevensdragers in beslag genomen (telefoons, navigatie, gps-tracker, iPad etc.). Het openbaar ministerie verzette zich in de 552a-procedure voor de rechtbank tegen teruggave nu er nog onderzoeksbelang anwezig was. Bij inbeslagneming op basis van artikel 94 Sv staan centraal de waarheidsvinding, ook wat betreft het aantonen van wederrechtelijk verkregen voordeel als bedoeld in artikel 36e $\mathrm{Sr}$, en het verwijderen uit het maatschappelijke verkeer van voorwerpen waarvan de verbeurdverklaring of onttrekking aan het verkeer kan worden bevolen. In geval van een beklag van de beslagene tegen een op de voet van artikel $94 \mathrm{~Sv}$ gelegd beslag dient de rechter te beoordelen of het belang van strafvordering het voortduren van het beslag vordert. Het belang van strafvordering verzet zich tegen teruggave indien het veiligstellen van de belangen waarvoor artikel $94 \mathrm{~Sv}$ de inbeslagneming toelaat, het voortduren van het beslag nodig maakt. Dat is bijvoorbeeld het geval wanneer de desbetreffende voorwerpen kunnen dienen om de waarheid aan de dag te brengen ook in een zaak betreffende een ander dan de klager - of om wederrechtelijk verkregen voordeel aan te tonen. Voorts verzet het door artikel $94 \mathrm{~Sv}$ beschermde belang 